\title{
Testing of the Advanced Stirling Radioisotope Generator Engineering Unit at NASA Glenn Research Center
}

Edward J. Lewandowski

Glenn Research Center, Cleveland, Ohio 


\section{NASA STI Program . . . in Profile}

Since its founding, NASA has been dedicated to the advancement of aeronautics and space science. The NASA Scientific and Technical Information (STI) program plays a key part in helping NASA maintain this important role.

The NASA STI Program operates under the auspices of the Agency Chief Information Officer. It collects, organizes, provides for archiving, and disseminates NASA's STI. The NASA STI program provides access to the NASA Aeronautics and Space Database and its public interface, the NASA Technical Reports Server, thus providing one of the largest collections of aeronautical and space science STI in the world. Results are published in both non-NASA channels and by NASA in the NASA STI Report Series, which includes the following report types:

- TECHNICAL PUBLICATION. Reports of completed research or a major significant phase of research that present the results of NASA programs and include extensive data or theoretical analysis. Includes compilations of significant scientific and technical data and information deemed to be of continuing reference value. NASA counterpart of peer-reviewed formal professional papers but has less stringent limitations on manuscript length and extent of graphic presentations.

- TECHNICAL MEMORANDUM. Scientific and technical findings that are preliminary or of specialized interest, e.g., quick release reports, working papers, and bibliographies that contain minimal annotation. Does not contain extensive analysis.

- CONTRACTOR REPORT. Scientific and technical findings by NASA-sponsored contractors and grantees.
- CONFERENCE PUBLICATION. Collected papers from scientific and technical conferences, symposia, seminars, or other meetings sponsored or cosponsored by NASA.

- SPECIAL PUBLICATION. Scientific, technical, or historical information from NASA programs, projects, and missions, often concerned with subjects having substantial public interest.

- TECHNICAL TRANSLATION. Englishlanguage translations of foreign scientific and technical material pertinent to NASA's mission.

Specialized services also include creating custom thesauri, building customized databases, organizing and publishing research results.

For more information about the NASA STI program, see the following:

- Access the NASA STI program home page at http://www.sti.nasa.gov

- E-mail your question to help@sti.nasa.gov

- Fax your question to the NASA STI Information Desk at 443-757-5803

- Phone the NASA STI Information Desk at 443-757-5802

- Write to: STI Information Desk NASA Center for AeroSpace Information 7115 Standard Drive Hanover, MD 21076-1320 
NASA/TM-2013-217854

AIAA-2012-4253

\section{Testing of the Advanced Stirling Radioisotope Generator Engineering Unit at NASA Glenn Research Center}

Edward J. Lewandowski

Glenn Research Center, Cleveland, Ohio

Prepared for the

10th International Energy Conversion Engineering Conference (IECEC)

sponsored by the American Institute of Aeronautics and Astronautics

Atlanta, Georgia, July 30-August 1, 2012

National Aeronautics and

Space Administration

Glenn Research Center

Cleveland, Ohio 44135 


\section{Acknowledgments}

This work is funded through the NASA Science Mission Directorate, the Radioisotope Power Systems Program Office, and the U.S. Department of Energy. The author wishes to acknowledge the many people who supported ASRG Engineering Unit (EU) testing in the Stirling Research Laboratory at the NASA Glenn Research Center.

This report contains preliminary findings, subject to revision as analysis proceeds.

Trade names and trademarks are used in this report for identification only. Their usage does not constitute an official endorsement, either expressed or implied, by the National Aeronautics and Space Administration.

Level of Review: This material has been technically reviewed by technical management.

Available from

NASA Center for Aerospace Information 7115 Standard Drive

Hanover, MD 21076-1320
National Technical Information Service 5301 Shawnee Road Alexandria, VA 22312 


\title{
Testing of the Advanced Stirling Radioisotope Generator Engineering Unit at NASA Glenn Research Center
}

\author{
Edward J. Lewandowski \\ National Aeronautics and Space Administration \\ Glenn Research Center \\ Cleveland, Ohio 44135
}

\begin{abstract}
The Advanced Stirling Radioisotope Generator (ASRG) is a high-efficiency generator being developed for potential use on a Discovery 12 space mission. Lockheed Martin designed and fabricated the ASRG Engineering Unit (EU) under contract to the Department of Energy. This unit was delivered to NASA Glenn Research Center in 2008 and has been undergoing extended operation testing to generate long-term performance data for an integrated system. It has also been used for tests to characterize generator operation while varying control parameters and system inputs, both when controlled with an alternating current (AC) bus and with a digital controller. The ASRG EU currently has over 27,000 hours of operation. This paper summarizes all of the tests that have been conducted on the ASRG EU over the past 3 years and provides an overview of the test results and what was learned.
\end{abstract}

\section{Introduction}

The Advanced Stirling Radioisotope Generator (ASRG) is moving closer to flight readiness and is being considered for use on NASA Discovery class and other Space Science missions. The ASRG system integration contractor Lockheed Martin Space Systems Company, under contract to the Department of Energy, is currently fabricating a Qualification Unit, which will be completed and tested in 2013. Previously, Lockheed Martin designed and built an Engineering Unit (EU). The EU's generator assembly was completed in December 2007 and controller integration followed in March 2008. The EU underwent a series of system-level tests to qualification level thermal and dynamic environments at Lockheed Martin. These included thermal balance, thermal vacuum performance, mechanical disturbance, sine transient, random vibration, simulated pyrotechnic shock, and electromagnetic interference (Refs. 1 and 2). Following inspection of the hardware, Lockheed Martin delivered the ASRG EU to the NASA Glenn Research Center (GRC) on August 28, 2008, for extended operation. The EU underwent inspection followed by integration into a test facility specially designed for the EU (Ref. 3). The ASRG EU began extended operation on November 6, 2008 and currently has over 27,000 hr (3.1 years) of operation. This test was intended to demonstrate extended operation of an integrated system, to monitor for trends in Stirling convertor performance, and to provide additional data from long-term operation of Stirling convertors. The test was not a life test of the EU, as it had been subjected to qualification level environmental testing.

Over the 3 years of operation, numerous tests have been conducted on the ASRG EU. Important findings from these tests have furthered the development of the Qualification and Flight generators. This paper summarizes these tests, documents how the ASRG EU has been operated, and provides an overview of the test results and what was learned. 


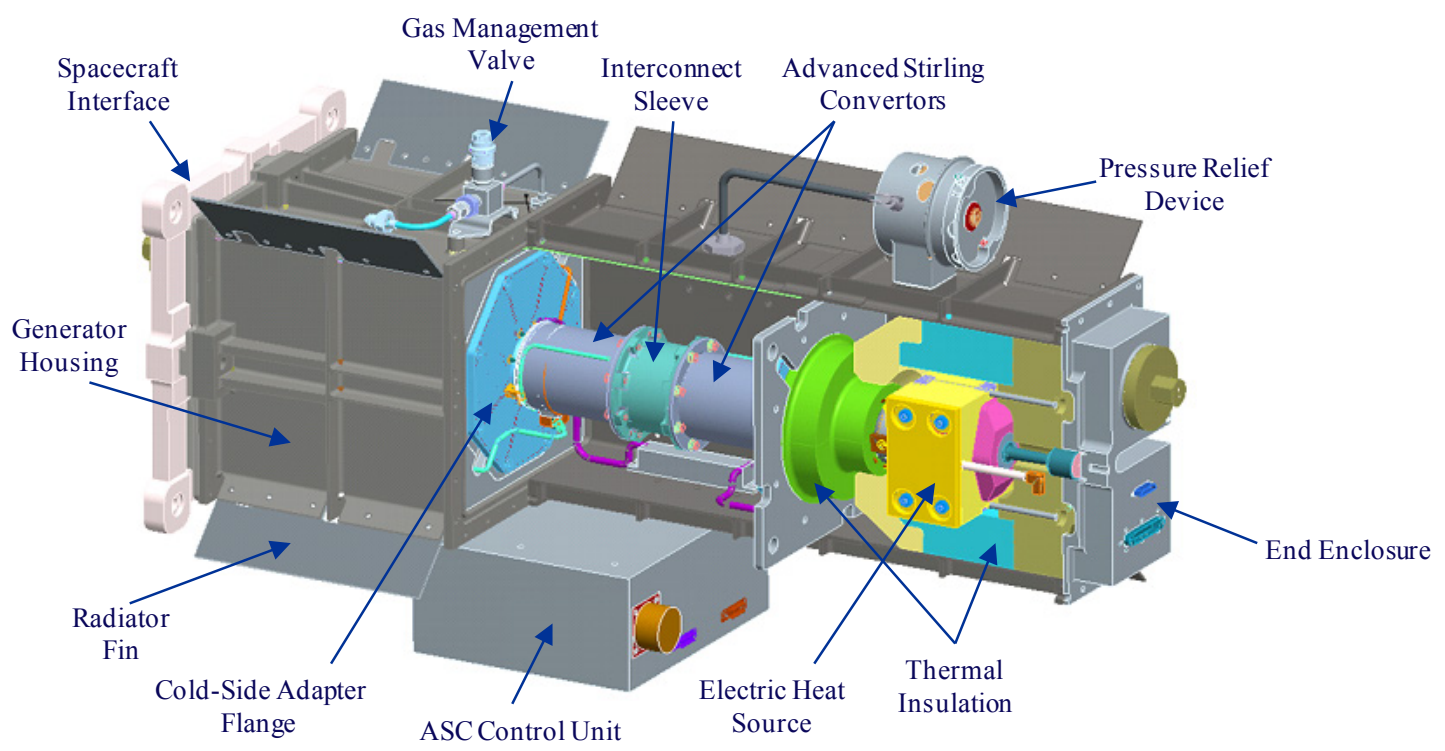

Figure 1.-ASRG EU cutaway view.

\begin{abstract}
ASRG EU
Figure 1 shows a cutaway of the ASRG EU. The EU contains two Advanced Stirling Convertors (ASC-Es) secured together with an interconnect sleeve. An electric heat source, held against each ASC-E heat collector, provides the heat input. The cold-side adapter flanges (CSAFs) conduct heat rejected from the convertors through the beryllium housing and fins, for radiation in a vacuum environment or convection to air. Argon fills the housing, sealed using o-rings and gaskets. A gas management valve allows access to the argon. A pressure relief device is provided to vent the argon during launch as the surrounding air pressure approaches the vacuum of space, improving effectiveness of the insulation surrounding the heat source. The controller is mounted to the outside of the housing. Connectors on the end enclosures, housing, and controller provide electrical interfaces to the alternators, sensors, power input and output, control, and telemetry. The EU is secured to a spacecraft interface or directly to its support via four mounting tabs on one end of the housing.
\end{abstract}

\title{
Differences Between the ASRG EU and the Flight ASRG Design
}

The ASRG EU differs in a number of ways from the current flight design. It is important to keep these differences in mind when utilizing test results from ASRG EU testing to assess implications for the flight system. Qualitatively, the principles and trends in behavior are expected to be similar, but characteristics will differ quantitatively. Some of the more significant differences in the current flight design that change characteristics of the generator include the following:

- Controller is no longer attached to the side of the generator but is mounted remotely on the spacecraft.

- Radiator fins on the Flight generator have increased in length from the ASRG EU radiator fins.

- Nominal convertor hot-end temperature increased as the maximum hot-end temperature increased from 650 to $850^{\circ} \mathrm{C}$.

- ASC alternator voltage was increased, with the number of turns in the alternator coil increased from 55 to 77 turns.

- Generator operating temperature range increased.

- Electrical shunts were moved from inside the housing to a ring-shaped shunt dissipation unit mounted on the outboard end of the generator. 


\section{ASRG EU Testing by Lockheed Martin}

The ASRG EU underwent a full suite of tests in late 2007 and 2008 at the Lockheed Martin Valley Forge facility. These tests demonstrated the EU's conformance to requirements and provided an opportunity to develop ground support test equipment and test procedures in preparation for flight hardware development. Key tests are summarized here, but are discussed in more detail in Reference 2.

- Thermal balance-ASRG EU was operated in a thermal vacuum chamber to provide data for thermal model validation.

- Thermal vacuum performance-Also performed in a thermal vacuum chamber, the thermal performance test cycled the EU over a temperature range beyond allowable flight temperatures, imposing thermal stresses on the assembly and verifying the design and workmanship.

- Sine transient-Verified that the ASRG EU response to sine transients in the 5 to $80 \mathrm{~Hz}$ range was within acceptable limits.

- Random vibration-ASRG EU was tested to qualification level in three axes.

- Simulated pyrotechnic shock-Demonstrated that the ASRG EU can withstand pyrotechnic shock. This test was tested to qualification level in two planes.

Periodically between these tests, the EU functional performance was verified to ensure that no degradation occurred. The testing at GRC was conducted after the EU had been stressed by the abovementioned tests and met associated requirements.

\section{ASRG EU Testing at GRC}

\section{ASRG EU Delivery to GRC}

After completion of testing at Lockheed Martin Valley Forge, the ASRG EU was shipped to NASA GRC to begin extended operation. The EU was shipped, not operating, in a Convertor Shipping Container (CSC) shown in Figure 2. The CSC was one of the containers used to transport Radioisotope Thermoelectric Generators, with an adapter plate incorporated to hold the ASRG.

A detailed procedure was followed to remove the ASRG EU from the CSC and install it in the Stirling Research Laboratory at GRC. All lifts were treated as critical lifts, commensurate with the highvalue hardware that was being moved.

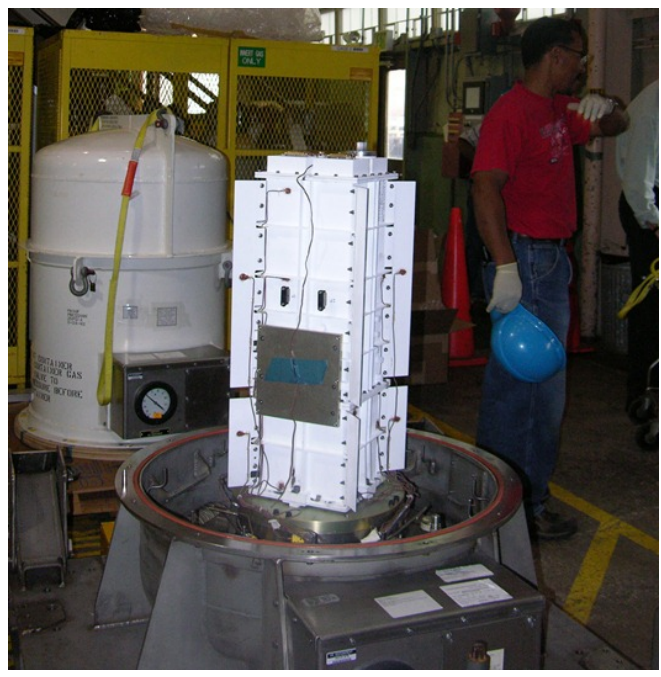

Figure 2.-ASRG EU mounted to shipping container with cover dome removed and in background. 


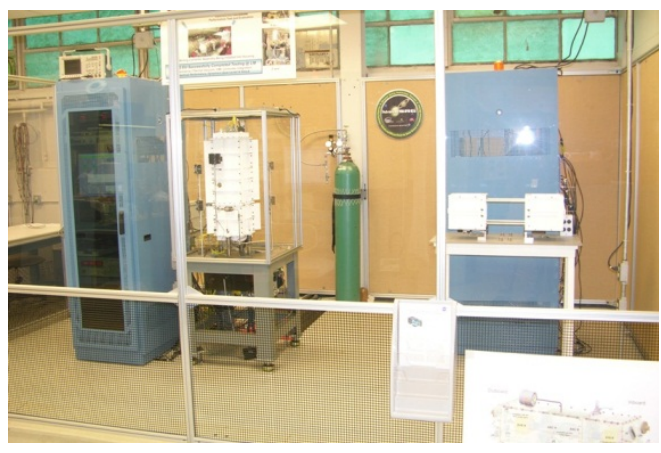

Figure 3.-ASRG EU test facility.

\section{ASRG EU Test Facility}

Figure 3 shows the test facility at GRC. The ASRG EU was mounted on a test table through stand-offs and was surrounded by a Lexan cage. Ductwork, fans, heat exchangers, and plumbing to a circulator (not shown) for cooling all reside underneath the table. The test rack, which contains the power supplies, the instrumentation, the computer, and the data acquisition, control, and monitoring system, was placed to the left of the test table. An argon cylinder and associated gas management hardware was mounted behind the test table. Framed Lexan partitions surround the test facility. Further details on the test facility can be found in Reference 3. Details about the test rack and data acquisition system can be found in Reference 4.

Data were collected during the entire operation of the ASRG EU. The LabVIEW (National Instruments) system records most parameters every 2 seconds ("2-second data"). Every hour the 2-second data are averaged over 5 minutes ("5-minute average") and saved to a data file. These 5-minute averages are what are shown in the figures in this paper. More recently the process of archiving the 2-second data has been automated. The parameters that are monitored on the ASRG EU and the test facility are listed in the appendix.

\section{Summary Overview of ASRG EU Testing}

The ASRG EU represents the highest fidelity ASRG built to date. At GRC the ASRG has operated for over 27,000 hr, and continues on test. Of the total operating time, 15,378 hr were under Engineering Development Unit (EDU) 1 ASC Controller Unit (ACU) control, with the remainder under AC bus control, except for a brief period ( $32 \mathrm{hr}$ ) of operation under EDU 2 ACU control. EDU 1 is the firstgeneration controller built for the EU. EDU 2 is the second-generation controller, and later generations have since followed. Lockheed Martin operated the ASRG EU for over 1,000 hr prior to delivery to GRC (Ref. 2). ASRG EU operation and major activity at GRC is summarized in Table I. The convertors were operated with fixed hot-end temperature for the first 5,234 hr, meaning that the heat input to the hot end was adjusted to maintain a fixed hot-end temperature. Remaining operation maintained fixed heat input and allowed the hot-end temperature to vary, which is closer to how the flight ASRG will be powered, with GPHS modules providing fixed heat input regardless of temperature.

For the majority of time the ASRG EU was cooled using forced convection-cooled air was flowed around the EU, and small fans directed air at the housing, facilitating heat transfer and maintaining more constant heat rejection temperatures. For a few brief periods, the cage surrounding the EU was removed, and the EU was cooled by natural convection alone. Neither of these cooling methods is representative of the radiative heat transfer environment seen in the vacuum of space.

The convertor operating frequency was adjusted during testing. The recommended operating frequency of $102.2 \mathrm{~Hz}$ was used initially for the first 3,907 hr. After that, the operating frequency was increased to $102.9 \mathrm{~Hz}$ because of frequency resolution limitations of the EDU $1 \mathrm{ACU}$. The EDU $1 \mathrm{ACU}$ cannot command exactly $102.2 \mathrm{~Hz} ; 102.9 \mathrm{~Hz}$ was the closest it can operate. In order to compare EU performance under ACU control versus AC bus control, all subsequent operation has been at the higher operating frequency, except for the brief period of operation under EDU $2 \mathrm{ACU}$ control at $102.2 \mathrm{~Hz}$. 
TABLE I.-ASRG EU OPERATION AND MAJOR ACTIVITY AT GRC

\begin{tabular}{|c|c|c|c|}
\hline Date & Hours & Duration & Activity \\
\hline 28 Aug 08 & & & ASRG EU delivered to NASA GRC from Lockheed Martin \\
\hline $\begin{array}{l}28 \text { Oct } 08 \text { to } 10 \\
\text { Aug } 09\end{array}$ & 0 to 5,234 & 5,234 & $\begin{array}{l}\text { Extended operation under AC bus control, fixed hot-end temperature } \\
\text { (varying heat input) }\end{array}$ \\
\hline 10 Jun 09 & 3,907 & & $\begin{array}{l}\text { Changed operating frequency under AC bus control from } 102.2 \text { to } 102.9 \mathrm{~Hz} \\
\text { to match EDU } 1 \text { ACU operating frequency }\end{array}$ \\
\hline $\begin{array}{l}8 \text { Sept } 09 \text { to } 27 \\
\text { Jan } 10\end{array}$ & $\begin{array}{c}5,234 \text { to } \\
8,191\end{array}$ & 2,957 & $\begin{array}{l}\text { Extended operation under EDU } 1 \text { ACU control, fixed heat input (varying } \\
\text { hot-end temperature) }\end{array}$ \\
\hline $\begin{array}{l}28 \text { Sept } 09 \text { to } 16 \\
\text { Oct } 09\end{array}$ & $\begin{array}{c}5,313 \text { to } \\
5,749\end{array}$ & 436 & ASC voltage setpoint and DC bus voltage variation test \\
\hline $\begin{array}{l}2 \text { Nov } 09 \text { to } 13 \\
\text { Nov } 09\end{array}$ & $\begin{array}{c}6,122 \text { to } \\
6,386\end{array}$ & 264 & ASC voltage setpoint and DC bus voltage variation test \\
\hline $\begin{array}{l}30 \text { Nov } 09 \text { to } 14 \\
\text { Dec } 09\end{array}$ & $\begin{array}{c}6,795 \text { to } \\
7,129\end{array}$ & 334 & Heat input variation test under EDU 1 ACU control \\
\hline 23 to 24 Dec 09 & $\begin{array}{c}7,346 \text { to } \\
7,385\end{array}$ & 39 & DC bus voltage variation test \\
\hline 25 Jan 10 & $\begin{array}{l}8,142 \text { to } \\
8,144\end{array}$ & 2 & DC bus voltage variation test \\
\hline $\begin{array}{l}29 \text { Jan } 10 \text { to } 22 \\
\text { Feb } 10\end{array}$ & $\begin{array}{l}8,191 \text { to } \\
8,766\end{array}$ & 575 & $\begin{array}{l}\text { Extended operation under AC bus control, fixed heat input (varying hot-end } \\
\text { temperature) }\end{array}$ \\
\hline $\begin{array}{l}1 \text { Feb } 10 \text { to } 4 \\
\text { Feb } 10\end{array}$ & $\begin{array}{c}8,259 \text { to } \\
8,331\end{array}$ & 72 & AC bus voltage variation test \\
\hline $\begin{array}{l}5 \text { Feb } 10 \text { to } 17 \\
\text { Feb } 10\end{array}$ & $\begin{array}{c}8,356 \text { to } \\
8,647\end{array}$ & 291 & Heat input variation test under AC bus control \\
\hline $\begin{array}{c}17 \text { Feb } 10 \text { to } 22 \\
\text { Feb } 10\end{array}$ & $\begin{array}{c}8,647 \text { to } \\
8,766\end{array}$ & 119 & Pressure vessel temperature variation test under AC bus control \\
\hline $\begin{array}{l}24 \mathrm{Feb} 10 \text { to } 19 \\
\text { Mar } 10\end{array}$ & $\begin{array}{c}8,766 \text { to } \\
9,292\end{array}$ & 526 & Extended operation under EDU 1 ACU control, fixed heat input \\
\hline $\begin{array}{c}24 \text { Mar } 10 \text { to } 26 \\
\text { Mar } 10\end{array}$ & $\begin{array}{c}9,292 \text { to } \\
9,324\end{array}$ & 32 & Operation under EDU 2 ACU control \\
\hline $\begin{array}{l}31 \text { Mar } 10 \text { to } 24 \\
\text { Jun } 10\end{array}$ & $\begin{array}{c}9,324 \text { to } \\
11,312\end{array}$ & 1,988 & Extended operation under EDU 1 ACU control, fixed heat input \\
\hline 4 Apr 10 & $\begin{array}{c}9,448 \text { to } \\
9,449\end{array}$ & 1 & Controller card interaction test \\
\hline 6 to 9 Apr 10 & $\begin{array}{c}9,465 \text { to } \\
9,538\end{array}$ & 73 & DC bus voltage variation test \\
\hline $\begin{array}{c}25 \text { Jun } 10 \text { to } 11 \\
\text { Oct } 11\end{array}$ & $\begin{array}{c}11,312 \text { to } \\
14,970\end{array}$ & 9,897 & Extended operation under EDU 1 ACU control, fixed heat input \\
\hline $\begin{array}{c}21 \text { Sept } 10 \text { to } 25 \\
\text { Oct } 10\end{array}$ & $\begin{array}{c}13,111 \text { to } \\
13,636\end{array}$ & 525 & Natural convection cooling test \\
\hline $\begin{array}{l}31 \text { Oct } 11 \text { to } \\
\text { present }\end{array}$ & $\begin{array}{c}21,219 \text { to } \\
\text { present }\end{array}$ & $\begin{array}{l}\text { Over } \\
5,800\end{array}$ & Extended operation under AC bus control, fixed heat input \\
\hline
\end{tabular}




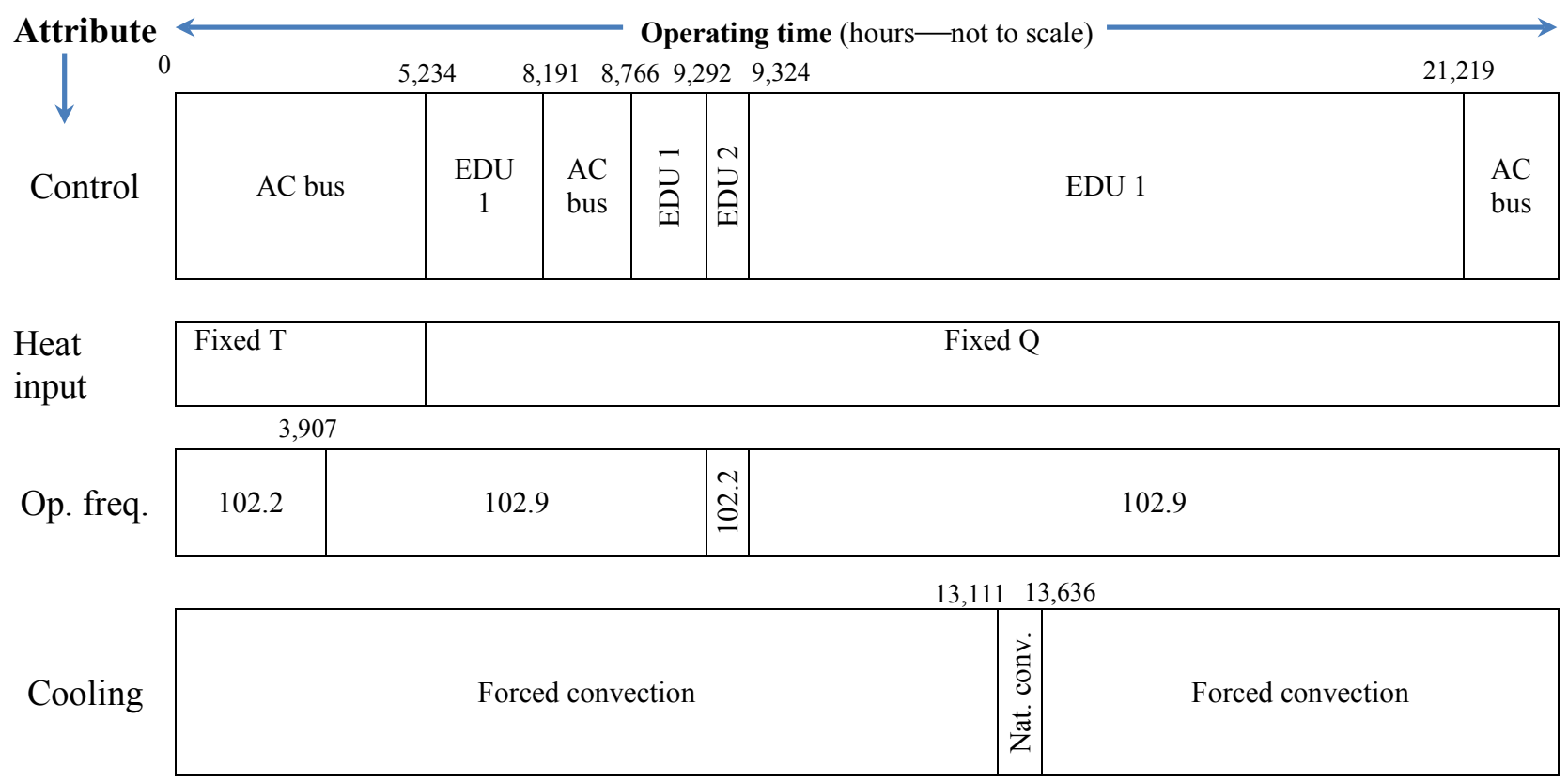

Figure 4.-Timeline: ASRG EU operation at GRC (not to scale).

Lockheed Martin's controller design consists of three cards to control the two ASC convertors. One card controls each convertor, and the third card serves as a spare. If a fault is detected on either of the two cards, control switches to the spare card. This design improves overall reliability by providing single fault tolerance. During EU testing, the control of ASC B was switched a number of times between controller card 2 to controller card 3 . ASC A was always operated on controller card 1.

The ASRG EU has been started and stopped about 35 times to date. This does not include the starts and stops at Lockheed Martin and convertor starts and stops at Sunpower, the convertor manufacturer.

The longest continuous period of operation under EDU 1 ACU control was 2,115 hr. The longest period of continuous operation so far under AC bus control was 4,367 hr. Annual shutdowns for instrumentation recalibration limited continuous operation to no more than about 8,000 hr. The data in Table I are shown graphically in Figure 4.

\section{Detailed Chronology of ASRG EU Operation at GRC}

\section{Early Operation Under AC Bus Control}

Early operation of the ASRG EU in 2008 and 2009 focused on maintaining steady operation under AC bus control. Figure 5 shows schematically the ASRG EU under AC bus control. During this period the hot-end temperature was fixed and input power was allowed to vary to maintain hot-end temperature. Figure 6 shows power fluctuating and often rising over time for almost the first 5,000 hours of operation. This variation in power was traced to changes in test rack wiring impedance. The ASC-E convertors have alternators with low voltage and high current. As a consequence, small variations in line impedance effectively change the load on the convertors, changing the piston amplitude and the output power. The electrical connector in the EU housing already adds impedance between the ASCs and the ACU. The alternator connector in the housing was selected for a different convertor with high voltage and low current. (ASC-E3 and Flight convertors operate at higher voltage and lower current than the ASC-E and ASC-E2 convertors.) Simulations showed that just a $10 \mathrm{~m} \Omega$ increase in impedance would cause a measurable change in operating point resulting in an increase in power. A number of improvements were implemented to resolve impedance variation issues. These include: 
- Eliminating spade lug connectors to tuning capacitors and replacing with soldered wires.

- Eliminating all other spade lug connectors and replacing with soldered or screw terminal connections.

- Replacing relays with hermetically sealed relays with low impedance variation.

These improvements were implemented in two steps: at 2,197 and 4,749 hr. Steady performance from 4,749 to $5,234 \mathrm{hr}$ shows the effectiveness of these improvements.

At 3,907 hours the operating frequency was changed from 102.2 to $102.9 \mathrm{~Hz}$. While the ASC manufacturer Sunpower recommends operating the ASC-E convertors at $102.2 \mathrm{~Hz}$, resolution limitations in the EDU $1 \mathrm{ACU}$ resulted in the closest operating frequency being $102.9 \mathrm{~Hz}$. The $0.7 \mathrm{~Hz}$ difference has a small measurable effect on convertor performance, and since one of the test objectives was to compare performance of the convertors under AC bus control versus ACU control, it was necessary to change the operating frequency under AC bus control to match the EDU 1 ACU operating frequency. EDU 2 and later ACUs have higher resolution and are able to operate at $102.2 \mathrm{~Hz}$.

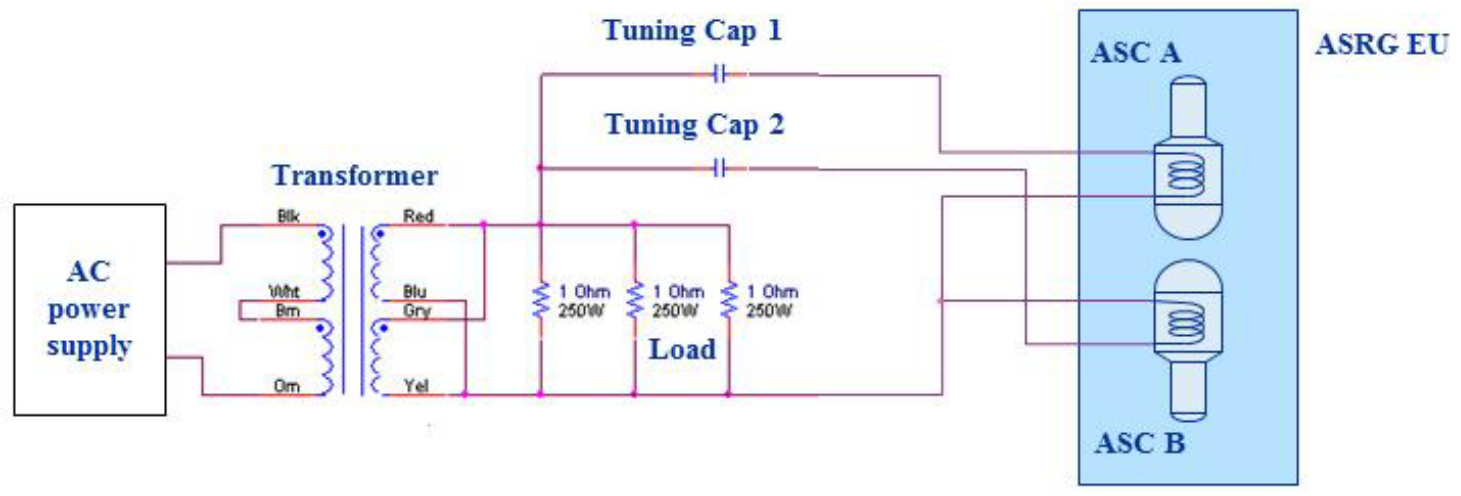

Figure 5.-Schematic of ASRG EU under AC bus control.

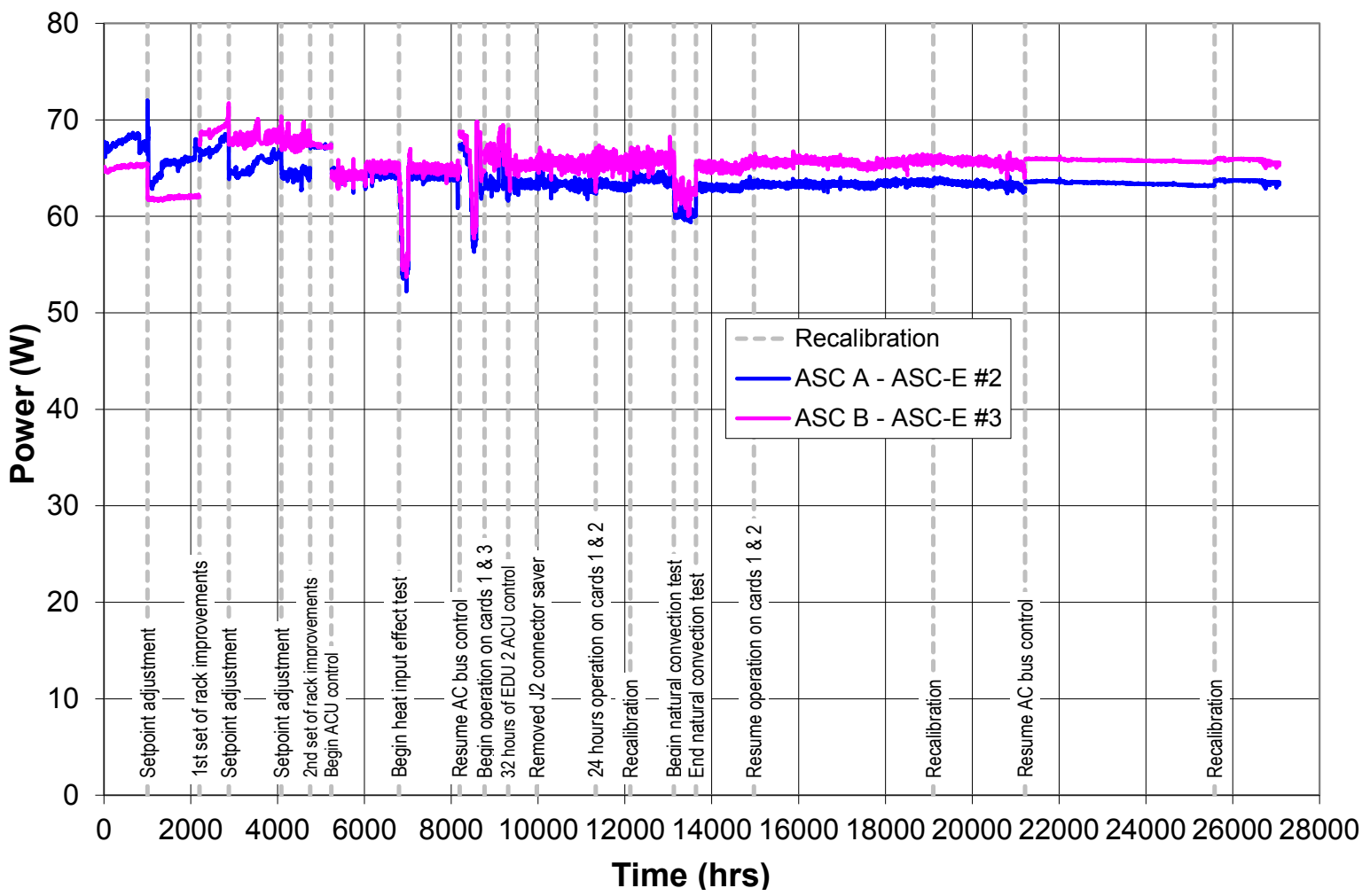

Figure 6.-Convertor output power from the ASRG EU. 


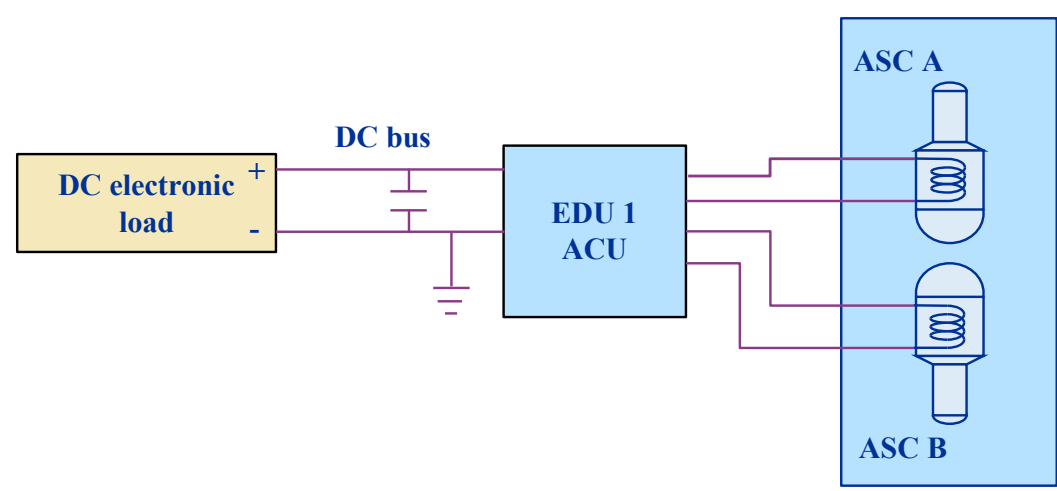

ASRG EU

Figure 7.-Schematic of ASRG EU under EDU 1 ACU control.

\section{Initial Operation Under EDU 1 ACU Control}

The EDU 1 ACU was not delivered to GRC with the ASRG EU but arrived on December 12, 2008. Lockheed Martin conducted other tests with EDU 1, including piston position sensor characterization and core loss measurement, prior to EDU 1 being mated to the generator. On September 8, 2009, at 5,234 hr, the ASRG EU began operation under EDU 1 ACU control at GRC. Figure 7 shows schematically the ASRG EU under ACU control.

\section{Tests Under EDU 1 ACU Control}

The fundamental testing of the EDU 1 ACU involved characterizing basic performance of the system under ACU control:

- ASC stability under ACU control

- ACU stability and drift

- ASC voltage setpoint command resolution

- Operating frequency command resolution

- Performance under different control modes

The EDU 1 ACU was designed with three control loops which can be active simultaneously - voltage control, temperature control, and piston amplitude control. The voltage control loop controls the voltage to the ASC alternator based on a commanded voltage setpoint and alternator current feedback. The temperature control loop limits hot-end temperature based on feedback from a resistance temperature detector (RTD) mounted on the ASC heat collector. This control loop was never exercised as the RTD did not survive in the hot-end temperature environment. Temperature control is not part of the flight design. The piston amplitude control loop set the piston amplitude based on feedback from the fast linear displacement transducer (FLDT). This control loop was exercised and did regulate piston amplitude. However, since the flight design incorporates voltage control only, voltage control was used for the majority of EDU 1 testing. The piston amplitude control loop gains were set so that loop was not active.

A number of characterization tests were conducted with EDU 1 to quantify performance of an integrated convertor-controller system. These tests included the ASC voltage setpoint variation, DC bus voltage variation, and heat input variation tests. Over a mission, the thermal environment, electrical load, and operating commands will affect the ASRG, and these tests were intended to mimic these effects and observe the response.

In the ASC voltage setpoint variation test, the key control input to the ACU was varied, and the generator response was observed. The ASC voltage setpoint is the voltage command sent to the ACU. Increasing ASC voltage setpoint increases piston amplitude, and decreasing ASC voltage setpoint decreases piston amplitude. Note though, that ASC voltage setpoint is not the only parameter that determines the piston amplitude. The piston amplitude is determined by the ASC voltage setpoint in 
conjunction with the heat input and operating temperatures of the convertor. The ASC voltage setpoint is roughly analogous to the AC bus voltage setpoint when operating a convertor with an AC bus controller.

In the DC bus voltage variation test the DC bus voltage was varied from 24 to $34 \mathrm{VDC}$. The purpose of this test was to determine if varying DC bus voltage affected ASC operation, and if so, by how much. Ideally, changing the DC bus voltage should not affect ASC operation. The ACU should maintain steady ASC operation regardless of DC bus voltage. In reality, depending on the controller topology, the ACU generally requires some compensation loop to achieve insensitivity to DC bus voltage. The DC bus voltage variation test characterized how ASC operation changed with DC bus voltage.

Over the 17-year design life of the ASRG, the heat output of a nominal 250-W GPHS module will decrease by 12.6 percent or about $31.4 \mathrm{~W}$ due to radioisotope decay. The heat input variation test simulated the radioisotope decay by decreasing heat input, and then observing the effect on the ASRG. As heat input decreased, the hot-end temperature decreased. When the ASRG is operated in flight, the piston amplitudes will likely be decreased in order to increase system efficiency by maintaining higher hot-end temperatures. Part of the heat input variation test included determining how much piston amplitude had to be decreased to maintain hot-end temperature.

The EDU 1 ACU tests identified a number of issues with the controller which needed to be addressed. Some of the findings included

- Piston amplitude "jitter." The piston amplitude was not steady but varied considerably from cycle to cycle. This was resolved by control algorithm change.

- Operating frequency resolution was too coarse, so the operating frequency could not be set to the recommended value of $102.2 \mathrm{~Hz}$. This was resolved by improving resolution.

- Significant (several degree) phase difference between controller cards 1 and 2, resulting in the dynamic forces from the two convertor pistons not being cancelled. This was resolved by improving the controller card synchronization design.

- EDU 1's ASC voltage setpoint resolution by design was $1 / 8 \mathrm{~V}$. Testing showed this was too coarse and did not permit the fine adjustment likely needed at some points in the mission. Later controllers significantly improved resolution.

- Inaccuracy in some of the telemetry. This was corrected in later controllers.

- Changing DC bus voltage resulted in a higher than allowable change in the hot-end temperature. This was resolved with control algorithm improvements in later controllers.

- Slow drift in control output. This was resolved with several design improvements to later controllers.

Extensive effort went into determining root causes of the above-mentioned issues, both at GRC and at Lockheed Martin. This activity included special tests of the ASRG EU, review and analysis of circuits and algorithms, and simulation. Subsequent to the EDU 1 ACU build, Lockheed Martin built and tested second and third generation controllers, EDU 2 and EDU 3. The issues identified during EDU 1 testing have now been resolved, and EDU 3 has demonstrated significant improvements over EDU 1.

\section{Return to Operation Under AC Bus Control}

Some of the issues identified with EDU 1 affected the results of the ASC voltage setpoint variation test, the heat input variation test, and other tests. To separate the effects of EDU 1 from the rest of the system (ASC-E convertors and generator housing), tests were conducted on the ASRG EU under AC bus control. The results from tests conducted under AC bus control should indicate how an ideal system would behave. The ASRG EU was shut down and restarted under AC bus control in January, 2010. Tests included the $\mathrm{AC}$ bus voltage variation, heat input variation, and cold-end and pressure vessel temperature variation tests. 
The AC bus voltage variation test is analogous to the ASC voltage setpoint variation test under ACU control. A change in AC bus voltage has a similar effect as a change in the ASC voltage setpoint.

The heat input variation test was conducted in a similar manner to the way it was conducted when operating under ACU control.

The cold-end and pressure vessel temperature variation test was not conducted previously when operating under ACU control. The purpose of this test was to characterize the effect of varying rejection temperatures. The ASRG rejects low-temperature heat through the fins and surfaces of the generator. The surface temperatures are expected to vary during the course of the mission due to factors such as change in proximity and orientation with respect to the Sun, the amount of heat being rejected, and other factors. The generator surface temperatures determine the Stirling convertor cold-end temperatures and pressure vessel temperatures. For this test the surface temperature of the ASRG EU housing was adjusted to vary cold-end temperatures and pressure vessel temperatures.

The results of these tests conducted under AC bus control have been documented in Reference 5 and will not be discussed further in this paper.

\section{Resume Operation Under EDU 1 ACU Control; Brief Operation Under EDU 2 ACU Control}

After completing ASRG EU characterization under AC bus control, operation returned to EDU 1 ACU control on February 24, 2010. The ASC convertors were connected to controller cards 1 and 3 instead of cards 1 and 2. Card 3 is considered the spare card, which is to be used when a failure is detected on either controller card 1 or 2 . The purpose of changing cards was to provide information to help understand some of the ACU issues identified previously, such as the phase difference between controller cards 1 and 2.

A core loss test was conducted to quantify power losses due to the switching controller versus an AC bus controller. The control algorithm in the ACU eliminates the need for tuning capacitors used with AC bus control by synthesizing the effect of the tuning capacitors and driving the ASC alternator through a pulse width modulation (PWM)-driven H-bridge (Ref. 6). The effect of the high-frequency switching is to increase magnetic core losses in the alternator relative to losses when the alternator is driven at the nominal $102.2 \mathrm{~Hz}$ operating frequency. Core losses result from the effect of discrete voltage steps on the alternator versus a perfect sine wave. The core loss test was conducted by operating the ASRG EU on AC bus control at a particular operating point and measuring output power, then shutting down and restarting under ACU control and again measuring output power. (Data from previous AC bus operation was used for comparison, so the ASRG EU wasn't shut down for this particular test.) It was important when measuring output power under ACU control that the power meter filtering was turned off so that the highfrequency power effects from the PWM switching were taken into account. The core loss was measured to be about $2.5 \mathrm{~W}$ per convertor. Improvements in the switching circuitry and control have reduced the core losses with the EDU 3 ACU.

During this time Lockheed Martin built a second ACU, EDU 2, with modifications to correct issues found in EDU 1. Lockheed Martin brought that controller to GRC to test it on the ASRG EU and assess improvements made to the controller. From March 24 to 26, 2010, the ASRG EU was operated under EDU 2 ACU control. EDU 2 demonstrated improved operating frequency resolution, reduced controller card phase difference, less jitter, and other improvements.

A brief test was conducted to quantify controller card interaction. Each ASC interfaces to one controller card in the ACU, and the controller cards should be essentially independent of each other. The degree of independence was assessed by commanding changes to one ASC and observing if any changes occurred in the operation of the other ASC. No interactions among the controller cards were observed on EDU 1. 
Around this time one of the cables between the EDU 1 ACU and the ASCs inside the EU started failing. This cable was not part of the ASRG EU but was a cable fabricated by GRC for test purposes. The resistance of one of the wires in the cable gradually increased, causing the ASC B's piston amplitude to rise. In response, the ASC voltage setpoint had to be decreased to maintain piston amplitude. The defective cable was eventually identified and repaired.

In September and October 2010, a natural convection cooling test was conducted on the ASRG EU to quantify temperatures and operating parameters with natural convection only to determine if the EU could be safely operated in such an environment. During most of the ASRG EU testing at GRC, heat rejection from the EU has been accomplished by circulating cooled air around the EU in a Lexan cage (Fig. 3). Auxiliary fans were incorporated to improve heat transfer through forced convection from the ASRG EU housing to the air. For the natural convection test the air around the ASRG EU was made as quiescent as possible. The cage was removed, fans were turned off, and plastic sheeting was set up to minimize drafts from the facility HVAC system. The results from the natural convection cooling test show that the ASRG EU was able to maintain acceptable operating temperatures throughout the generator with significant margins with natural convection cooling alone. Results from this test are documented in Reference 7.

Around October 2010, ASC B's piston amplitude began to slowly drift down and the hot-end temperature began to drift upward. This issue was investigated over the next several months. The cause was narrowed down to one of the controller cards, and likely to a circuit that is no longer used in the current flight controller design.

\section{Current Operation Under AC Bus Control}

By October 2011, there was little more that could be learned from further operation of EDU 1. Lockheed Martin used EDU 1 test results in the development of EDU 2 and EDU 3. Because of significant differences between the flight controller design and EDU 1, it was very unlikely that any other issues would be uncovered. Further, since the ASC-E convertors in the ASRG EU had over 20,000 hours of operation, it would be more valuable to operate under AC bus control so that operation could be more precisely controlled and the convertor performance could be monitored for changes over time.

On October 31, 2011, the ASRG EU returned to operation under AC bus control, where it continues to operate, and has now over $27,000 \mathrm{hr}$.

\section{Conclusion}

The ASRG EU performed an important role in ASRG development. As the first (and only to date) engineering unit, it successfully integrated Stirling convertors with an electronic controller in a housing suited for radioisotope fuel. It served as a pathfinder for many of the manufacturing processes, assembly procedures, and tests. Testing at NASA GRC demonstrated extended capability of the ASC-E convertors and the EDU 1 controller. The EDU 1 controller was a first-ever redundant controller whose control strategy integrated three control modes. Although it had some issues, it proved the viability of the control approach and paved the way for the later generations of the controller (EDU 2 and EDU 3, to be followed by the flight-like EDU 4). Special tests conducted on the EU provided valuable insight into characteristics and nuances of performance of the system. Lessons learned and refinements to the test facility have benefitted later test racks and electrical ground support equipment being developed for the Qualification and Flight systems. 



\section{Appendix-Parameters Monitored on the ASRG EU}

This appendix lists the parameters monitored on the ASRG EU.

\begin{tabular}{|c|c|}
\hline Parameter & Description and details \\
\hline $\begin{array}{l}\text { Heater voltage, } \\
\text { current, power, } \\
\text { resistance }\end{array}$ & $\begin{array}{l}\text { DC voltage and current measured using OSI transducers up to 5,234 hr. Yokogawa WT230 power } \\
\text { meter used thereafter. Power and resistance are calculated from heater voltage and current. }\end{array}$ \\
\hline $\begin{array}{l}\text { ASC alternator } \\
\text { voltage and current }\end{array}$ & $\begin{array}{l}\text { OSI AC voltage and current transducers used up to 5,234 hr. Yokogawa WT230 power meter used } \\
\text { thereafter. The ACU telemetry also provides an analog signal which is converted into an RMS value, } \\
\text { and provides digital telemetry of peak-to-peak current. }\end{array}$ \\
\hline ASC alternator power & $\begin{array}{l}\text { AC power, not corrected for losses in leads from ASC feed throughs and connectors. OSI power } \\
\text { transducers used up to } 5,234 \mathrm{hr} \text {. Yokogawa WT230 power meter used thereafter. }\end{array}$ \\
\hline $\begin{array}{l}\text { ASC alternator power } \\
\text { factor }\end{array}$ & $\begin{array}{l}\text { Calculated from ASC alternator voltage, current, and power up to 5,234 hr. Yokogawa WT230 power } \\
\text { meter used thereafter. }\end{array}$ \\
\hline $\begin{array}{l}\text { AC bus voltage, } \\
\text { current, power }\end{array}$ & Yokogawa WT230 power meter measured AC bus electrical parameters. \\
\hline $\begin{array}{l}\text { ACU input voltage, } \\
\text { power }\end{array}$ & $\begin{array}{l}\text { Added voltage measurement close to input to ACU to more accurately measure ACU input power. } \\
\text { Yokogawa WT230 power meter added at } 12,124 \mathrm{hr} \text {. }\end{array}$ \\
\hline $\begin{array}{l}\text { DC bus voltage, } \\
\text { current, power }\end{array}$ & Yokogawa WT230 power meter measures DC bus electrical parameters from the ACU. \\
\hline Operating frequency & $\begin{array}{l}\text { Operating frequency was measured by the Yokogawa power meters and calculated from the FLDT } \\
\text { signals. }\end{array}$ \\
\hline Heater temperature & Two thermocouples in each heat source measure heater temperature. \\
\hline Hot-end temperature & $\begin{array}{l}\text { The RTD sensors installed on the heater head did not survive and therefore were not utilized. Seven } \\
\text { thermocouples on each heater head measure temperature hot-end temperatures at various locations. }\end{array}$ \\
\hline CSAF temperature & Two thermocouples and a thermistor measure near the ID of the CSAF, close to the heat rejector \\
\hline Cold-end temperature & Calculated from CSAF temperature; is slightly higher than CSAF temperature \\
\hline $\begin{array}{l}\text { Pressure vessel } \\
\text { temperature }\end{array}$ & $\begin{array}{l}\text { A thermocouple and a thermistor measure temperature on the outside surface of the convertor pressure } \\
\text { vessel that surrounds the alternator. }\end{array}$ \\
\hline $\begin{array}{l}\text { Generator housing } \\
\text { assembly (GHA) } \\
\text { temperatures }\end{array}$ & $\begin{array}{l}20 \text { thermocouples are mounted on the GHA at various locations. Thermocouples mounted near the } \\
\text { ASC CSAF are used to provide a representative temperature for the GHA. }\end{array}$ \\
\hline $\begin{array}{l}\text { ACU controller card } \\
\text { temperatures }\end{array}$ & $\begin{array}{l}\text { The ACU provides digital telemetry with controller card temperature from a temperature sensor } \\
\text { mounted on each controller card. }\end{array}$ \\
\hline $\begin{array}{l}\text { Surrounding air } \\
\text { temperatures }\end{array}$ & Temperatures of the air circulating around the ASRG are measured at various locations. \\
\hline $\begin{array}{l}\text { Ambient air } \\
\text { temperature }\end{array}$ & A thermocouple monitored ambient air temperature near the test rack. \\
\hline $\begin{array}{l}\text { ASC piston } \\
\text { amplitude }\end{array}$ & $\begin{array}{l}\text { Each ASC-E has an internal FLDT. When operating under AC bus control, the FLDT signal from each } \\
\text { ASC was processed by stand-alone Lockheed Martin-provided FLDT processors. When operating } \\
\text { under ACU control, the ACU's internal FLDT processor provided an analog signal proportional piston } \\
\text { position which is converted to piston amplitude. The ACU also provides piston stroke as digital } \\
\text { telemetry. }\end{array}$ \\
\hline $\begin{array}{l}\text { ASC mean piston } \\
\text { position }\end{array}$ & A relative measure of mean position was calculated from the FLDT signal. \\
\hline $\begin{array}{l}\text { Piston phase } \\
\text { difference }\end{array}$ & $\begin{array}{l}\text { Phase difference between the two ASC pistons. Phase meter added at } 12,124 \mathrm{hr} \text { to measure this } \\
\text { parameter. }\end{array}$ \\
\hline Argon pressure & Argon pressure within the GHA. \\
\hline Interface force & $\begin{array}{l}\text { Tri-axial Kistler 9251A load cells measure the net dynamic force generated by the moving parts within } \\
\text { the two ASC-E convertors at the interface between the generator and the table. }\end{array}$ \\
\hline Interface acceleration & A tri-axial accelerometer measures acceleration on one of the four legs supporting the generator. \\
\hline ACU start-up current & $\begin{array}{l}\text { Current from auxiliary DC power supply to power the ACU during start-up measured using Yokogawa } \\
\text { WT210 power meter. Not recorded by LabVIEW system. }\end{array}$ \\
\hline ACU telemetry & $\begin{array}{l}\text { All other digital telemetry are recorded from the ACU. Telemetry includes internal voltages, status } \\
\text { information, etc. }\end{array}$ \\
\hline
\end{tabular}




\section{References}

1. Chan, J., Wood, J.G., and Schreiber, J.G., "Development of Advanced Stirling Radioisotope Generator for Space Exploration," proceedings of Space Technology and Applications International Forum (STAIF 2007), edited by M.S. El-Genk, AIP Conference Proceedings 880, pp. 615-623, 2007; NASA/TM-2007-214806.

2. Chan, J., Hill, D., Hoye, T, and Leland, D., "Development of Advanced Stirling Radioisotope Generator for Planetary Surface and Deep Space Missions," Proceedings of the Sixth International Energy Conversion Engineering Conference (IECEC 2008) American Institute for Aeronautics and Astronautics, 2008.

3. Lewandowski, E.J., et al., "Design of a Facility to Test the Advanced Stirling Radioisotope Generator Engineering Unit," Proceedings of the Seventh International Energy Conversion Engineering Conference (IECEC 2009) American Institute for Aeronautics and Astronautics, 2009.

4. Dugala, G., "Test Rack Development for Extended Operation of Advanced Stirling Convertors at NASA Glen Research Center," Proceedings of the Seventh International Energy Conversion Engineering Conference (IECEC 2009) American Institute for Aeronautics and Astronautics, 2009.

5. Lewandowski, E.J. and Schreiber, J.G., "Testing to Characterize the Advanced Stirling Radioisotope Generator Engineering Unit," Proceedings of the Eighth International Energy Conversion Engineering Conference (IECEC 2010), American Institute for Aeronautics and Astronautics, 2010.

6. Holliday, E.S., "Controller Computing a Virtual Tuning Capacitor for Controlling a Free-Piston Stirling Engine Driving a Linear Alternator,” U.S. Patent 7,511,459, March 31, 2009.

7. Lewandowski, E.J. and Hill, D., "Natural Convection Cooling of the Advanced Stirling Radioisotope Generator Engineering Unit," Proceedings of the Nuclear and Emerging Technologies for Space 2011, Albuquerque, N.M., February 7-10, 2011. 



\begin{tabular}{|c|c|c|}
\hline \multicolumn{2}{|c|}{ REPORT DOCUMENTATION PAGE } & $\begin{array}{l}\text { Form Approved } \\
\text { OMB No. 0704-0188 }\end{array}$ \\
\hline \multicolumn{3}{|c|}{ 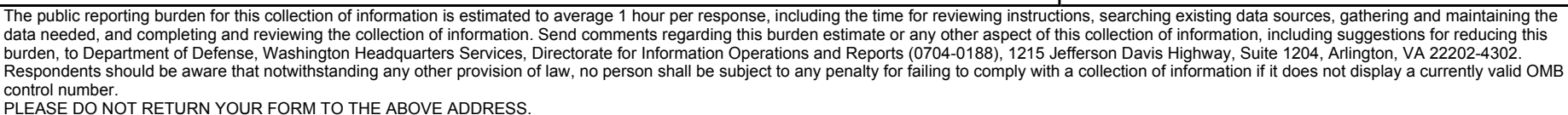 } \\
\hline $\begin{array}{l}\text { 1. REPORT DATE (DD-MM-YYYY) } \\
01-11-2013\end{array}$ & $\begin{array}{l}\text { 2. REPORT TYPE } \\
\text { Technical Memorandum }\end{array}$ & 3. DATES COVERED (From - To) \\
\hline \multirow{3}{*}{\multicolumn{2}{|c|}{$\begin{array}{l}\text { 4. TITLE AND SUBTITLE } \\
\text { Testing of the Advanced Stirling Radioisotope Generator Engineering Unit at NASA Glenn } \\
\text { Research Center }\end{array}$}} & 5a. CONTRACT NUMBER \\
\hline & & 5b. GRANT NUMBER \\
\hline & & 5c. PROGRAM ELEMENT NUMBER \\
\hline \multirow{3}{*}{\multicolumn{2}{|c|}{$\begin{array}{l}\text { 6. AUTHOR(S) } \\
\text { Lewandowski, Edward, J. }\end{array}$}} & 5d. PROJECT NUMBER \\
\hline & & 5e. TASK NUMBER \\
\hline & & $\begin{array}{l}\text { 5f. WORK UNIT NUMBER } \\
\text { WBS } 138494.01 .99 .01\end{array}$ \\
\hline \multicolumn{2}{|c|}{$\begin{array}{l}\text { 7. PERFORMING ORGANIZATION NAME(S) AND ADDRESS(ES) } \\
\text { National Aeronautics and Space Administration } \\
\text { John H. Glenn Research Center at Lewis Field } \\
\text { Cleveland, Ohio 44135-3191 }\end{array}$} & $\begin{array}{l}\text { 8. PERFORMING ORGANIZATION } \\
\text { REPORT NUMBER } \\
\text { E-18275 }\end{array}$ \\
\hline \multirow{2}{*}{\multicolumn{2}{|c|}{$\begin{array}{l}\text { 9. SPONSORING/MONITORING AGENCY NAME(S) AND ADDRESS(ES) } \\
\text { National Aeronautics and Space Administration } \\
\text { Washington, DC 20546-0001 }\end{array}$}} & $\begin{array}{l}\text { 10. SPONSORING/MONITOR'S } \\
\text { ACRONYM(S) } \\
\text { NASA }\end{array}$ \\
\hline & & $\begin{array}{l}\text { 11. SPONSORING/MONITORING } \\
\text { REPORT NUMBER } \\
\text { NASA/TM-2013-217854 }\end{array}$ \\
\hline \multicolumn{3}{|c|}{$\begin{array}{l}\text { 12. DISTRIBUTION/AVAILABILITY STATEMENT } \\
\text { Unclassified-Unlimited } \\
\text { Subject Category: } 20 \\
\text { Available electronically at http://www.sti.nasa.gov } \\
\text { This publication is available from the NASA Center for AeroSpace Information, 443-757-5802 }\end{array}$} \\
\hline
\end{tabular}

\section{ABSTRACT}

The Advanced Stirling Radioisotope Generator (ASRG) is a high-efficiency generator being developed for potential use on a Discovery 12 space mission. Lockheed Martin designed and fabricated the ASRG Engineering Unit (EU) under contract to the Department of Energy. This unit was delivered to NASA Glenn Research Center in 2008 and has been undergoing extended operation testing to generate long-term performance data for an integrated system. It has also been used for tests to characterize generator operation while varying control parameters and system inputs, both when controlled with an alternating current (AC) bus and with a digital controller. The ASRG EU currently has over 27,000 hours of operation. This paper summarizes all of the tests that have been conducted on the ASRG EU over the past 3 years and provides an overview of the test results and what was learned.

15. SUBJECT TERMS

Stirling engines; Performance tests; Controllers; Radioisotope batteries

\begin{tabular}{|c|c|c|c|c|c|}
\hline \multicolumn{3}{|c|}{ 16. SECURITY CLASSIFICATION OF: } & \multirow{2}{*}{$\begin{array}{l}\text { 17. LIMITATION OF } \\
\text { ABSTRACT } \\
\text { UU }\end{array}$} & \multirow{2}{*}{$\begin{array}{l}\text { 18. NUMBER } \\
\text { OF } \\
\text { PAGES } \\
22\end{array}$} & \multirow{2}{*}{$\begin{array}{l}\text { 19a. NAME OF RESPONSIBLE PERSON } \\
\text { STI Help Desk (email:help@sti.nasa.gov) } \\
\text { 19b. TELEPHONE NUMBER (include area code) } \\
\text { 443-757-5802 }\end{array}$} \\
\hline $\begin{array}{l}\text { a. REPORT } \\
U\end{array}$ & $\begin{array}{l}\text { b. ABSTRACT } \\
U\end{array}$ & $\begin{array}{l}\text { c. THIS } \\
\text { PAGE } \\
\text { U }\end{array}$ & & & \\
\hline
\end{tabular}



